\title{
Extent and financial cost of cassava postharvest loss along the cassava value chain in Kwara State, Nigeria
}

\author{
Samuel Temitope DANILOLA ${ }^{1,2}$, Raphael BABATUNDE ${ }^{1}$, Jubril ANIMASHAUN ${ }^{1}$
}

Received May 02, 2018; accepted October 01, 2019.

Delo je prispelo 02. maja 2018, sprejeto 01. oktobra 2019.

\begin{abstract}
Extent and financial cost of cassava postharvest loss along the cassava value chain in Kwara State, Nigeria

Abstract: Cassava has been identified as Africa's second most important staple food after maize, in terms of calories consumed, with Nigeria as the World leading producer. This study estimated postharvest loss of cassava along the cassava value chain in Kwara State. It estimated the size of postharvest loss of cassava; analysed the factors responsible and the financial implications of loss; and identified the strategies employed in the mitigation of loss in the study area. A threestage random sampling technique was used to select 117 cassava farmers whom were administered structured questionnaire to elicit data analysed by the study. Descriptive statistics, Shannon's diversity index and Tobit regression model were the analytical techniques utilised. The results show that $68 \%$ of the loss occurred at the harvesting. The loss was estimated to be about $3.8 \mathrm{tha}^{-1}$. The financial implication was valued at $\$ 300 \mathrm{ha}^{-1}$. Analysis of the factors responsible for cassava postharvest loss showed that the quantity expected at harvesting, household size and age of the farmer were significant factors affecting cassava postharvest loss. The result also revealed that farmers mitigate these losses by processing the roots and reburying unused roots into the soil. Steps needed to reduce loss have to take these factors into consideration to improve the economic status of cassava farmers-processors.

Key words: cassava; postharvest loss; financial cost; Shannon's diversity index; Tobit regression
\end{abstract}

Obseg in stroški izgube $\mathrm{v}$ pridelovalni verigi manioke po spravilu pridelka v državi Kwara, Nigeria

Izvleček: Manioka je postala za koruzo v Afriki druga najpomembnejša vsakodnevna hrana glede zaužitih kalorij, z Nigerijo kot vodilnim svetovnim pridelovalcem. V raziskavi je bila ocenjena velikost izgube pridelka manioke po spravilu. Analizirani so bili dejavniki, odgovorni za izgubo in njene finančne posledice. Identificirane so bile strategije, ki so bile uporabljene za blaženje izgub na preučevanem območju. Uporabljena je bila tristopenska metoda vzorčenja, v kateri je bilo 117 pridelovalcev manioke, ki so izpolnili vprašalnik za pridobitev podatkov analiziranih $\mathrm{v}$ tej raziskavi. Za analizo pridobljeni podatkov so bile uporabljenne metode opisne statistike, Shannonov diverzitetni indeks in Tobit regresijski model. Rezultati kažejo, da je 68 \% izgube nastalo med spravilom. Izguba je bila ocenjena na okrog $3,8 \mathrm{t} \mathrm{ha}^{-1}$, njena vrednost pa $\$ 300 \mathrm{ha}^{-1}$. Analiza dejavnikov, odgovornih za izgubo pridelka manioke po spravilu je pokazala, da so bili pri tem najpomembnejši velikost pričakovanega pridelka, velikost gospodinjstev in starost pridelovalcev. Rezultati so še pokazali, da pridelovalci zmanjšujejo izgubo pridelka po spravilu s predelovanje in ponovnim zakopavanjem v tla. Koraki, potrebni za zmanjšanje izgube pridelka so torej upoštevanje teh dejavnikov in s tem izboljšati ekonomičnost predelave manioke pri pridelovalcih

Ključne besede: manioka; izguba po spravilu; finančna ocena; Shannonov diverzitetni indeks; Tobit regresija

1 University of Ilorin, Department of Agricultural Economics and Farm Management, Ilorin, Kwara State, Nigeria

2 Corresponding author, e-mail: samueldanilola@yahoo.com 


\section{INTRODUCTION}

Cassava (Manihot esculenta Crantz.) is a member of the family of Euphorbiaceae, and is one of the oldest cultivated crops by human beings although the early history of cassava is still a mystery (Gulick et al., 1983). It was reported that cassava has been cultivated in northern Amazonia more than 1000 years ago (Jones, 1959) until some years back when it was postulated that cassava is likely to be originated from wild M. esculenta populations along the southern region of the Amazon basin (Olsen et al., 2001). Portuguese explorers introduced cassava to Africa during the 16th and 17th centuries through their trade with the African coasts and nearby islands. Africans then spread cassava further, and it is now found in almost all parts of tropical Africa. Today Nigeria and Democratic Resepublic of Congo are the largest producers of cassava in Africa alongside Brazil in the South America and Carribeans and Thailand in Asia (Department of Agriculture, Forestry and Fisheries, South Africa, 2010). Figure 1 shows the world production of cassava and the revenue generated from the sale of the commodity in dollars.

Cassava (M. esculenta) is Africa's second most important staple, after maize, in terms of calories consumed, with Nigeria as the world leading producer (Nweke, 2004). This is as a result of cassava's combined abilities to produce high yields under poor conditions and store its harvestable portion underground until when needed and this had made it a classic "food security crop" (Nweke, 2003). Its importance as a food crop in Africa can be clearly seen when consumption data from Africa is compared with other cassava growing regions of the world, majorly the Latin Americas. Cassava is very important in the diet of an average Nigerian. It has comparative production advantage over other staples; as a result this serves to encourage its cultivation even by the resource-poor farmers. Studies on cassava has shown that it accounts for about $70 \%$ of the total calorie intake of more than half of Nigerians (Nweke and Enete, 1999) with its starchy roots producing more food energy per unit of land than any other staple crop in the country (de Figueroa et al., 2001).

However, despite cassava being a major constituent of the diet and also major source of income to farmers in Nigeria as a whole and specifically Kwara state, economically, it represents a wasted investment that can reduce farmers' incomes and increase consumers' expenses (Lipinski et al., 2013). Although, the level of the impact of the postharvest loss of this crop has not yet been seen from literatures, neither is the part it plays in attaining food security known. It is equally important to note that, even with our status as the leading producer of cassava in the world, we are still behind Thailand in the exportation of cassava products, and we still import some by-products of cassava processing such as industrial starch. Moreover, environmentally, postharvest loss inflict a host of impacts, including unnecessary greenhouse gas emissions and inefficiently used water and land, which in turn can lead to diminished natural ecosystems and the services they provide (Lipinski et al., 2013).

Considering the fact that, despite the prevalence of post-harvest food loss in Nigeria, there are limited studies quantifying the losses of roots and tubers, especially cassava, in Nigeria. There is therefore a need for this study on the post-harvest loss of cassava as a major constituent of Nigerian diet. Thus, the knowledge of the

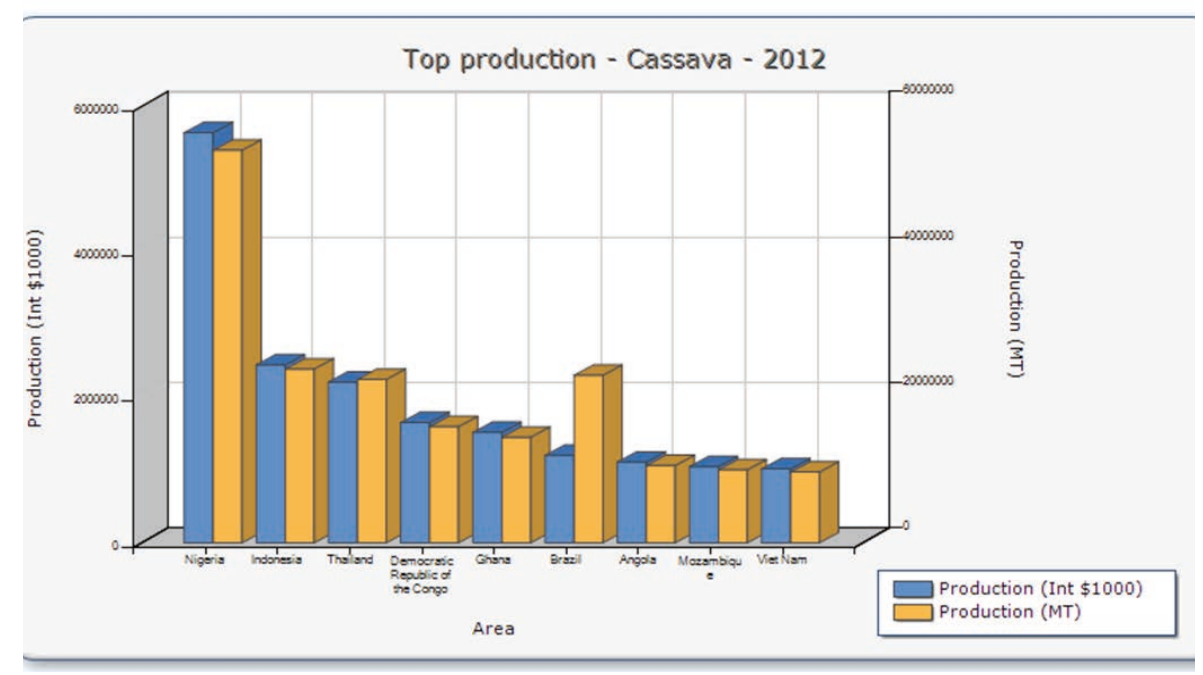

Figure 1: Graph of top cassava producers in the world as at year 2012. Source: FAOSTAT, 2013. 
level and extents of postharvest losses of cassava along the cassava supply chain and their major effects would be necessary, as it would provide policy makers with the required findings to enact and implement policies needed to prevent/or mitigate these losses, and as such ensure victory in the war against food insecurity in Kwara state specifically, and global warming, in general.

In the light of the foregoing, the study was carried out to estimate the size/index of postharvest loss of cassava along the supply chain in the study area, analyse factors responsible for the postharvest losses of cassava along the supply chain, analyse the financial cost implication(s) of postharvest losses in the study area and examine the strategies employed in the mitigation of postharvest losses in the study area.

\section{MATERIALS AND METHODS}

The study was carried out in Kwara State whose capital is Ilorin. Kwara State of Nigeria was created on the $27^{\text {th }}$ of May, 1967 along with 11 other states of the federation. The state was originally called west central state, having been carved out of the defunct northern Nigeria. At the time of creation, the state had a landmass of but this has reduced to following the boundary adjustments that accompanied excision of a segment of its eastern part to Benue State in 1976 and 6 local government areas to the present Kogi State and Niger State in 1991. However, recent survey shows that the state has a total land area of about which is about 3.5 of the total land area of the country, which is put at (KWSG, 2006).Considering the geographical location, Kwara State occupies a vantage position on the map of Nigeria. Situated between latitudes and of the equator and longitudes $\mathrm{E}$ and $\mathrm{E}$ of the equator, it lies midway between the Northern and Southern parts of Nigeria. Kwara State is divided into four zones by the Kwara State Agricultural Development Project (KWADP) in consonance with ecological characteristics, cultural practices and project's administrative convenience. These are: Zone A: Baruteen and Kaima Local Government Areas; Zone B: Edu and Patigi Local Government Areas; Zone C: Asa, Ilorin East, Ilorin South, Ilorin West and Moro Local Government Areas; and Zone D: Ekiti, Ifelodun, Irepodun, Offa, Oyun, Isin and Oke-ero Local Government Areas. The State shares boundaries with Osun, Oyo, Ondo, Kogi, Niger and Ekiti States as well as an international boundary with the Republic of Benin in the West.

The study was carried out in 2014 and a threestage random sampling technique was used to select the sample farmers for the study. In the first stage, one (1) out of the four (4) agricultural zones in Kwara State was selected at random, while ten (10) villages were randomly selected from the list of villages in the selected zone in the second stage. The final stage involved the random selection of twelve (12) cassava farmers from each of these villages, only the data of one hundred and seventeen (117) farmers were used for further analysis.

Primary data were collected through the use of structured questionnaire in an interview schedule method. Information was collected on the socio-economic characteristics of the farmers in the study area such as age, gender, education, farm size, etc. Also, information was collected on quantities of cassava harvested and processed, losses incurred along the supply chain, amongst others. Data collected were analyzed using descriptive statistics, Shannon's diversity index and Tobit regression model based on the objectives of the study.

The Shannon's Diversity Index, $\mathrm{H}$ was applied to measure the spread of the postharvest loss across the cassava value chain i.e. harvesting, processing and marketing. The index of postharvest losses was obtained from the formula:

$$
\mathrm{H}=-\sum_{\mathrm{i}}^{\mathrm{n}}={ }_{1} \mathrm{p}_{\mathrm{i}} \ln \mathrm{p}_{\mathrm{i}}
$$

Where, $\mathrm{H}=$ Shannon's diversity index for postharvest loss,

$n=$ number of stages in the value chain from which losses are recorded, and

$$
p_{i}=\frac{\left.N_{i} \text { (loss at each stage of the value chain }\right)}{\text { total postharvest loss }}
$$

The tobit regression model is a statistical model which describes the relationship between a non-negative dependent variable and an independent variable and supposes that there is a latent (observable) variable. The observable variable is defined to be equal to the latent variable whenever the latent variable is above zero (but not more than 1) and zero otherwise. This model was used in the determination of the latent variable due to the presence of a maximum amount of losses that can be accommodated, beyond which the postharvest losses become unacceptable.

The econometric model for the tobit regression is implicitly stated as:

$\mathrm{yi}^{*}=\beta \mathrm{x} 1+\beta \mathrm{x} 2+\beta \mathrm{x} 3+\beta \mathrm{x} 4+\beta \mathrm{x} 5+\beta \mathrm{x} 6+\beta \mathrm{x} 7+\mathrm{e}$

$\mathrm{yi}^{*}=$ percentage loss as a proportion of expected output $\left(0 \mathrm{yi}^{\star} 1\right)$

$\beta=$ coefficient to be estimated

$\mathrm{x} 1=$ age of respondents (years) 


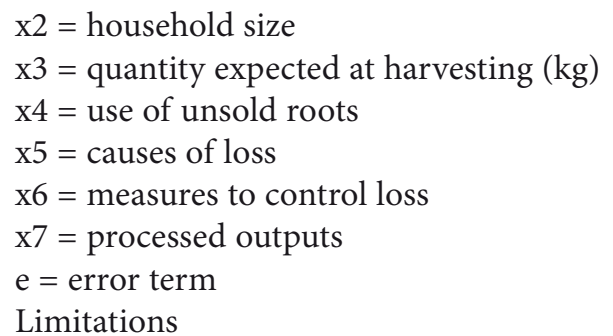

This study used recall process to elicit the losses across the different aspects of the value chain due to the poor record keeping characteristics of the farmers. Therefore, it is important to factor that in the interpretation of the result of the study.

\section{RESULTS AND DISCUSSIONS}

The results in table 2 show the socioeconomic characteristics of cassava farmers in the study area. It can be deduced from the table that $66.7 \%$ of the respondents were male and $33.3 \%$ female. The male dominance of cassava production as well as processing as against processing alone, which is female dominated (Ezedinma et al., 2007 and Muhammad-Lawal et al., 2013) could be majorly attributed to the combination of the cassava production and processing stages. The table further revealed that more than $60 \%$ of the respondents are more than 35 years but not older than 55 years of age and majority of the farmers are married and have at least a year of formal education. Also, it can be obtained from the table that the modal years of farming experience of the farmers was between 15 and 24 years while the modal annual income falls between $\mathrm{N} 25,001$ and $\mathrm{N} 181,000$.

Estimation of the size of cassava post-harvest loss shows that the average postharvest loss of cassava per hectare of farmland under cassava cultivation in the study area was $3.80 \mathrm{t} \mathrm{ha}^{-1}$.

Average postharvest loss per hectare $=$ total amount ofpostharvest loss ofcassava total land under cassava cultivation

$$
=\underline{752.040 \mathrm{t}}=\underline{\underline{3.80 \mathrm{tha}^{-1}}}
$$

It can be deduced from table 1 that, the size of cassava postharvest loss is 752,040 kg which when expressed in percentage of total quantity expected is $33.34 \%$. The chain of highest loss is at harvesting which accounts for about $68 \%$ of the total loss, followed by the loss at processing, $22 \%$ and then loss at marketing, $10 \%$.The loss across the value chain is not uniformly distributed as revealed by a relatively low $\mathrm{H}$-value. The intensity of the loss at harvesting stage, being the highest, is in line with the report of Bokanga (1999) where he stated that postharvest loss of cassava is the highest at harvesting in dry season due to hardness of the soil which results in heavy breakage of the roots. This further confirms the findings of Jaspreet et al. (2013) which postulates that food losses occur majorly at the field-market stage.

Tobit regression model was used to model the factors responsible for cassava postharvest loss. It was assumed that the losses beyond a threshold is regarded as postharvest loss. Ten percent was the threshold used in this study.

Table 3 shows the Tobit regression result of the factors responsible for cassava postharvest loss. The result shows that the quantity expected at harvest, household size and age of the farmers are the significant factors that determine cassava postharvest loss in the study area at $5 \%$ level of significance. It can be deduced from the table that both the quantity expected at harvest and household size positively affects the postharvest loss of cassava. This implies the higher the quantity of cassava expected at harvesting, the more the margin of postharvest loss all things being equal. This is in conformity with the finding of Atanda et al. (2011) that postharvest loss could result when there is a bumper harvest which could overload the post-harvest handling system or exceed the consumption need and cause excessive wastage.

In a similar way, the household size was found to have a positive significant effect on cassava postharvest

Table 1: Shannon's diversity index for size/level of post-harvest loss in the study area

\begin{tabular}{llllll}
\hline $\begin{array}{l}\text { Stages of the cassava } \\
\text { value chain }\end{array}$ & $\begin{array}{l}\mathrm{N}_{\mathrm{i}} \text { (total loss at this } \\
\text { stage, } \mathrm{kg})\end{array}$ & $\mathrm{P}_{\mathrm{i}}$ & $\ln \mathrm{P}_{\mathrm{i}}$ & $\mathrm{H}=-\left(\mathrm{P}_{\mathrm{i}} \times \ln \mathrm{P}_{\mathrm{i}}\right)$ & $\begin{array}{l}\text { Percentage loss as a pro- } \\
\text { portion of total loss }(\%)\end{array}$ \\
\hline Harvesting & 509,200 & 0.68 & $-0,39$ & 0.26 & 68 \\
Processing & 166,790 & 0.22 & -1.51 & 0.33 & 22 \\
Marketing of roots & 76,050 & 0.10 & -2.29 & 0.23 & 10 \\
Total & 752,040 & & & 0.82 & 100 \\
\hline
\end{tabular}

Source: Data analysis, 2014. 
Table 2: Distribution of cassava farmers by their socioeconomic characteristics

\begin{tabular}{|c|c|c|}
\hline Variables & Frequency & Percentage (\%) \\
\hline \multicolumn{3}{|l|}{ Sex } \\
\hline Male & 78 & 66.7 \\
\hline Female & 39 & 33.3 \\
\hline \multicolumn{3}{|l|}{ Age (years) } \\
\hline$\leq 25$ & 1 & 0.9 \\
\hline $25-35$ & 1 & 0.9 \\
\hline $36-45$ & 27 & 23.1 \\
\hline $46-55$ & 50 & 42.7 \\
\hline $56-65$ & 32 & 27.4 \\
\hline$\geq 66$ & 6 & 5.1 \\
\hline \multicolumn{3}{|l|}{ Marital status } \\
\hline Single & 1 & 0.9 \\
\hline Married & 105 & 89.7 \\
\hline Widowed & 9 & 7.7 \\
\hline Divorced & 2 & 1.7 \\
\hline \multicolumn{3}{|l|}{ Years of schooling } \\
\hline 0 & 26 & 22.2 \\
\hline $1-6$ & 39 & 33.3 \\
\hline $7-12$ & 39 & 33.3 \\
\hline $13-16$ & 9 & 7.7 \\
\hline$\geq 17$ & 4 & 3.4 \\
\hline \multicolumn{3}{|c|}{ Farming experience (years) } \\
\hline$\leq 5$ & 4 & 3.4 \\
\hline $6-14$ & 29 & 24.8 \\
\hline $15-24$ & 34 & 29.1 \\
\hline $25-33$ & 25 & 21.4 \\
\hline $34-43$ & 19 & 16.2 \\
\hline$\geq 44$ & 6 & 5.1 \\
\hline \multicolumn{3}{|l|}{ Annual income $(\mathrm{N})$} \\
\hline$\leq 25,000$ & 9 & 7.7 \\
\hline $25,001-181,000$ & 80 & 68.4 \\
\hline $181,001-337,000$ & 23 & 19.7 \\
\hline $337,000-493,000$ & 3 & 2.6 \\
\hline$\geq 649,001$ & 2 & 1.7 \\
\hline
\end{tabular}

Source: Field survey, 2014.

loss at $5 \%$ level of significance. This implies the larger the household size of cassava farmers, the higher the percentage of cassava postharvest loss in the study area, leaving all other factors constant. Also found to significantly affect the level of cassava postharvest loss in the study area at $5 \%$ level was the age of cassava farmers but with a negative relationship. From Table 3, one can infer that a one year increase in the age of respondent would result in $0.33 \%$ reduction in postharvest loss. This is true especially when the increase in age comes with more farming-processing experience and large household size. The experience, in turn, results in improved harvesting-processing practices; experience is also known to have positive effect on processors' managerial capacity, technical know-how, and adoption of extension packages (Achem and Akangbe, 2011). All these lead to a reduced level of postharvest losses. However, the remaining factors modeled were found to be insignificant to the level of cassava postharvest loss in the study area.

The analysis carried out to examine the economic cost implication of the cassava postharvest loss shows cost implication is $\$ 300 /$ ha as shown below:

Cost of 1 tonne of cassava $=\$ 78.94 \mathrm{t}^{-1}$

Average postharvest loss $=3.80 \mathrm{tha}^{-1}$

Therefore, Cost of postharvest loss $=\$ 15,000.00$ $\mathrm{t}^{-1} \times 3.80 \mathrm{tha}^{-1}=\$ 300 \mathrm{ha}^{-1}$

Based on the work of Abduraheem and Toluwase (2013), cassava farmers earn $468,662.50$ per hectare; the postharvest loss is about $83.0 \%$ of the income earned on a hectare.

Table 4 shows the relative percentages of the respondents that practice each postharvest control measures. The respondents utilize a combination of the postharvest loss control measures as this could imply that the use of just one of the above could be insufficient for the control of the loss. It can be deduced from the table that, the most widely used measure by cassava farmers in the study area was harvesting the roots when required while the least used measure was use of agrochemicals. This implies that majority of the cassava farmers in the study area prefer to harvest the roots as at when required to mitigate the potential postharvest loss associated with cassava. This may be attributed to the fact that harvesting of roots when required will give no room for excesses as the desired quantity will be harvested and all possible efforts will be put in place to make sure any postharvest loss is kept at barest minimum.

\section{CONCLUSION AND RECOMMENDA- TIONS}

The study has shown that the size of the cassava postharvest loss of Kwara state is very high and concrete steps have to be taken in order to reduce this loss so as to improve upon the economic status of cassava farmers-processors. The concentration of losses at the 
Table 3: Tobit regression result for the factors responsible for cassava postharvest loss

\begin{tabular}{lllc}
\hline Percentage loss as a proportion of output & Coefficient & Standard Error & t- value \\
\hline Processed outputs (Kg) & -0.59 & 1.52 & 0.39 \\
Measures to control loss & -0.87 & 1.16 & -0.75 \\
Causes of loss & 2.20 & 1.36 & 1.61 \\
Use of unprocessed roots & -0.12 & 1.85 & -0.06 \\
Quantity expected at harvesting (Kg) & $2.80 \mathrm{e}^{-4}$ & $1.10 \mathrm{e}^{-4}$ & $2.54^{\star \star}$ \\
Household size & 1.36 & 0.47 & $2.90^{\star *}$ \\
Age (years) & -0.33 & 0.15 & $-2.18^{\star *}$ \\
Constant & 26.05 & 7.98 & 3.27 \\
Sigma & 12.94 & 0.89 & \\
\hline
\end{tabular}

Source: Data analysis, $2014{ }^{* *}$ indicate statistical significance of the coefficients at $5 \%$ level.

Table 4: Distribution of the Respondents According to Measures Employed to Control the Post-Harvest Loss

\begin{tabular}{|c|c|c|c|c|c|c|}
\hline \multirow[t]{2}{*}{ Measures Employed } & \multicolumn{2}{|l|}{ Yes } & \multicolumn{2}{|l|}{ No } & \multicolumn{2}{|l|}{ Total } \\
\hline & Frequency & Percentage (\%) & Frequency & Percentage (\%) & & \\
\hline Use of skilled workers & 12 & 10.3 & 105 & 89.7 & 117 & 100.0 \\
\hline Improved facilities & 17 & 14.5 & 100 & 85.5 & 117 & 100.0 \\
\hline Delayed harvesting & 20 & 17.1 & 97 & 82.9 & 117 & 100.0 \\
\hline Use of agrochemicals & 6 & 5.1 & 111 & 94.9 & 117 & 100.0 \\
\hline Harvesting when required & 47 & 40.2 & 70 & 59.8 & 117 & 100.0 \\
\hline Use of improved facilities & 25 & 21.4 & 92 & 78.6 & 117 & 100.0 \\
\hline
\end{tabular}

Source: Field survey, 2014.

harvesting stage calls for concern as there is the need for improved methods of mechanizing the harvesting process to reduce the losses at harvesting. Hence, reducing the losses at harvesting by a great percentage would imply a great reduction of the loss across the value chain. The factor responsible for postharvest loss like expected output (losses increase with increase in expected output) foretells a need to improve postharvest technology as this implies there are no adequate facilities to contain the excesses that may be harvested. From the result of the analysis of the study, the economic cost of the loss is $\$ 300 \mathrm{ha}^{-1}$, which if mitigated and reinvested into the economy would add a required impetus to boost farmers' income and other agribusiness concern and encourage farmers for better productivity. Also, it can be deduced from the findings of the study that the methods of cassava postharvest loss mitigation adopted by farmers are not adequate enough as there are still quite a number of losses at harvesting. Hence, there should be improvements in existing methods of mitigating losses.

The study therefore recommends that should be increased study on the alternative uses of cassava roots (e.g. ethanol production) in order to reduce the already choked garri, flour and starch market and also, concerns on losses at harvesting and methods of mitigating such losses should hold central point in economic policy development and researches. Also, reasonable policies should be implemented to help the farmers reduce the losses, especially by enforcing the use of cassava flour in confectionaries across the nation. This would ensure the optimal use of cassava, hence reducing its postharvest losses.

\section{REFERENCES}

Abduraheem, K. A and Toluwase, S. O. (2013). Costs and returns analysis of cassava production in Ekiti State, Nigeria. Journal of Agricultural Science, 3(10), 454-457. Available online at http://www.scholarly journals.com/SJAS.

Achem, B.A. and Akangbe, J.A. (2011). Assessment of Constraints to Cassava Value Added Enterprises in Kwara State, Nigeria. Journal of Agricultural Extension, 15(1), 124-134. 
Atanda, S. A., Pessu, P. O., Agoda, S., Isong, I. U. and Ikotun, I. (2011). The concepts and problems of postharvest food losses in perishable crops. African Journal of Food Science, 5(11), 603-613. Available online at http:// www.academicjournals.org/AJFS.

Bokanga, M. (1999). Cassava: Post-harvest Operations. International Institute of Tropical Agriculture (IITA), Ibadan. Food and Agriculture Organisation of the United Nations.

de Figueroa, L., Rubenstien, L., \& Gonzalez, C. (2001). Utilization of Native Cassava Starch by Yeasts. Food Microbiology Protocols Journal. Methods in Biotechnology, 14, 307-317. https://doi.org/10.1385/1-59259-029-2:307

Department of Agriculture, Forestry and Fisheries, South Africa (2010). Annual Report of the department of Agriculture, Forestry and Fisheries, The Republic of South Africa.

Ezedinma, C., Ojiako, I., Okechukwu, J., Lemehi,A., Umar, L., Sanni,M., Akoroda, F., Ogbe, E., Okoro, G., and Dixon, A. (2007): "The cassava food commodity market and trade network in Nigeria". IITA, Ibadan. Nigeria.

FAOSTAT, 2013. http://faostat.fao.org/DesktopModules/Faostat/Images/T20/ChartPic_d4zg47ghd0udm5xn8as3. png?eb37291b-a547-4acc-b987-31bc12fbac56.

Gulick, P., Hershey, C., and Esquinas A.J. (1983). Genetic Resources of Cassava and Wild Relatives. IBPGR/82/111, Rome, pp 8-45.

Jaspreet, A., Anita, R., Joan, F., and Corinne, A. (2013). Estimating Post-Harvest Food Losses: Developing a Consistent Global Estimation Framework. Selected Poster prepared for presentation at the Agricultural \& Applied Economics Association's 2013 AAEA \& CAES Joint Annual Meeting, Washington, DC, August 4-6, 2013.

Jones, W.O. (1959). Manioc in Africa. Stanford University Press, USA. pp 315.

Lipinski, B., Hanson, C., Lomax, J., Kitinoja, L., Waite, R., and Searchinger, T. (2013). "Reducing Food Loss and Waste."
Working Paper, Installment 2 of Creating a Sustainable Food Future. Washington, DC: World Resources Institute. Available online at http://www.worldresourcesreport.org. Muhammad-Lawal, A., Omotesho, O.A., and Oyedemi, F.A. (2013). An Assessment of the Economics of Cassava Processing in Kwara State, Nigeria. Invited paper presented at the 4th International Conference of the African Association of Agricultural Economists, September 22-25, 2013, Hammamet, Tunisia.

Nweke, F.I. (2003). New challenges in the cassava transformation in Nigeria and Ghana. Environment and Production Technology Division (EPTD). Discussion Paper No. 118, International Food Policy Research Institute, Washington DC, USA.

Nweke, F.I. (2004). "Cassava, A cash crop in Africa. A Collaborative Study of Cassava in Africa”. Working paper. No. 14.

Nweke, F.I., and Enete, A.A. (1999). Gender surprises in food production, processing and marketing emphasis on cassava in Africa: Collaborative Study of Cassava in Africa (COSCA). Working paper No. 19. COSCA, IITA, Ibadan, Nigeria.

Oguntade, A.E. (2013). Reducing Food Losses to Improve Food Security: An Analysis of Cassava and Maize Value Chains in Nigeria. Report delivered to the GIZ Gmbh, Bonn, Germany.

Olsen, K.M., and Schaal, B.A. (2001). Microsatellites variation in cassava (Manihot esculenta, Euphorbiaceae) and its wild relations: further evidence for a further evidence for a southern Amazonian origin of domestication. American Journal of Botany, 88, 131-142. https://doi. org/10.2307/2657133 